\title{
11. Slovakia
}

\section{Kamil Baraník}

\section{INTRODUCTION TO THE CONCEPT OF THE REFERENDUM IN SLOVAKIA}

Before 1992, the direct exercise of state power by the citizens in the territory that is now the sovereign Slovak Republic was a purely hypothetical possibility. Technically, the Czechoslovak Constitution of 1920 introduced limited prospects of direct involvement of the people into decision-making for the first time. The statutory regulation that would specify this constitutional commitment and would allow the Czechoslovak citizens to exercise this power in practice, however, was never adopted. ${ }^{1}$ Therefore direct democracy, especially in the form of the referendum, had never become prevalent in the first Czechoslovak constitutional regime. Many decades later, in 1992, the Act on Referendum, the first signal after 1920 that would encourage direct democracy, was adopted. This statutory device, however, came into force only in the dying seconds of the existence of the Czecho-Slovak Federation. Consequently, the envisioned instrument was never used in practice. Therefore, no referendum had been organized until $1992 .^{2}$

The constitutional entrenchment of the referendum by the newly established Slovak Republic was, thus, a continuation of a trend to take the direct will of the people into consideration in specific cases of national (or local) significance. Based on this experience, the inclusion of the referendum into the constitutional framework of the young republic could be denoted as an important historical event.

Despite theoretical unfamiliarity and utter practical inexperience with the forms of direct democracy, several leading academics have started to indicate that the Slovak Republic has been constitutionally constructed as a semi-direct

1 L’udmila Somorová, 'Referendum ako forma výkonu štátnej moci’ (2000) Pocta Jaroslavovi Chovancovi (Procom) 248-255.

2 Dušan Nikodým, 'Referendum v Ústave Slovenskej republiky' (1997) Právny obzor 21-22. 
democracy. ${ }^{3}$ This bold statement has been anchored to Article 2(1) of the Constitution of the Slovak Republic (Constitution), which stipulates that 'state power originates from citizens, who exercise it through their elected representatives or directly'. ${ }^{4}$ After 27 years of constitutional development, the reality, however, has proved that the exercise of the state power was far from an equal division between the citizens and their elected representatives. As the further text reveals, the cumbersome nature of some constitutional provisions regulating the referendum, combined with the political unwillingness to cooperate, have created major obstacles to the more frequent use of this traditional constitutional tool.

\section{EXISTING DIRECT-DEMOCRATIC INSTRUMENTS}

Theoretically, the Slovak constitutional regulation of the referendum can be divided into several categories. The most obvious one is to distinguish referendums on the basis of their territorial scope. In that regard, the Constitution differentiates between a referendum at the national ${ }^{5}$ and a referendum at the subnational level. A subnational referendum can be a municipal referendum or a referendum in a self-government regional unit. ${ }^{6}$

The most important (and constitutionally obvious) difference between these two groups is their legal force. While the referendum at the national level has been constitutionally designed as a legally binding tool of direct democracy, the Constitution remains completely silent on the effects of the referendum at the subnational level. ${ }^{7}$ The obligatory and optional forms of local referendums recognized under the statutory scheme have so far produced extremely limited consequences. Most commentators have suggested that this type of referen-

Marián Giba et al., Ústavné právo (Wolters Kluwer 2019) 209.

4 The Constitution of the Slovak Republic in English language is accessible here https://www.constituteproject.org/constitution/Slovakia_2017?lang=en, accessed 10 June 2020.

5 Art. 7(1) and Art. 93-100 Constitution.

6 Art. 67(1) Constitution.

7 Ján Drgonec, Ústava Slovenskej republiky. Teória a prax. 2. vydanie (C.H. Beck, 2019) 1122. 
dum may aspire to legally binding consequences. ${ }^{8}$ This, however, has not been reflected appropriately in a corresponding statutory regulation. ${ }^{9}$

At the national level, the Constitution distinguishes between the mandatory referendum (a law-initiated referendum that confirms the decision of the constitution-making body) and the optional referendum ${ }^{10}$ (that can be initiated either by the legislative body or by a specific number of citizens). ${ }^{11}$ At the subnational level, the Constitution only creates a distinction between a municipal referendum and a referendum in a self-government regional unit. ${ }^{12}$ The statutory regulation implicitly recognizes the existence of a mandatory and an optional referendum at the subnational level.

The national referendum is constitutionally framed in Article 2(1), Article 7(1) and in a separate subchapter titled 'Referendum' (Articles 93-100) of Chapter Five ('Legislative Power'). The specificities of the referendum process are stipulated in Act no. 180/2014 Coll. on the conditions of the exercise of the right to vote (Articles 196-215). The subnational referendum is constitutionally outlined in Article 67(1) and statutorily regulated in Act no. $369 / 1990$ Coll. on the municipal establishment (the referendum at the municipal level) and in Act no. 302/2001 Coll. on the self-government regional units (the referendum on the level of self-government regional unit).

Since the introduction of the original Constitution in 1992, the wording of the provisions dealing with the issue of the national referendum has been quite ambiguous and offered various, often contradictory interpretations. ${ }^{13}$ Therefore, it has been imperative to follow the case law of the Constitutional Court of the Slovak Republic (SCC). Despite the fact that the SCC dealt with this issue only three times, ${ }^{14}$ it sought to clarify the textually vague constitutional provisions. It succeeded only to a certain extent, thus the confusion about fundamental issues of the functioning of the referendum still remains.

Nowadays, the referendum symbolizes an ever-appealing option for direct decision-making by citizens in various relevant and sometimes controversial disputes. It is regularly elevated to national attention by heterogenous groups

8 See Ján Drgonec, Ústavné právo hmotné (C.H. Beck, 2018) 248-249; Lívia Trellová, Ústanoprávne aspekty územnej samosprávy (Wolters Kluwer, 2018) 141-147; Marek Domin, 'O adresátovi miestneho referenda. Nielen toho gabčíkovskeho' (2016) 68 Justičná revue 8-9, 879-882.

9 Radoslav Procházka, 'Miestne referendum a krajské referendum - 1. čast' (2009) 61 Justičná revue 10, 1159-1166.

10 Peter Kresák, 'The Government Structure in the New Slovak Republic' (1996) 4 Tulsa Journal of Comparative and International Law 1, 30-32.

11 Art. 95(1) Constitution.

12 Art. 67(1) Constitution.

13 Giba (n 3) 209.

14 Decisions PL. ÚS 42/95 (1996); II. ÚS 31/97 (1997); PL. ÚS 24/2014 (2014). 
of politicians, specialists, interest groups and NGOs. However, for many reasons that will be elaborated further in the text, the referendum epitomizes an example of a currently dysfunctional constitutional instrument that has been, perhaps opportunistically, mostly blocked by the politicians. They have not been willing to live up to the promise of Article 2 of the Constitution that stipulates the power-sharing between the citizens and their representatives in the exercise of the state power.

\subsection{Mandatory (Law-initiated) Referendum}

The Constitution distinguishes two main types of the referendum at the national level - mandatory and optional. According to the Constitution, there is only one possibility of how the mandatory referendum can be initiated. Article 7(1) stipulates that if the Slovak Republic decides to enter into (or withdraw from) a state union with other states, the decision shall be made by a constitutional law which has to be subsequently confirmed by a (mandatory) referendum. The very same rationale is reconfirmed in Article 93(1) of the Constitution, instructing: 'A referendum is used to confirm a constitutional law on entering into a union with other states, or on withdrawing from that union.' Therefore, this type of referendum is triggered by the decision of the Slovak Parliament to enter into (or withdraw from) a state union taken in the form of a constitutional law.

The requirement to confirm a constitutional statute by a referendum is arguably deduced from the highest democratic magnitude of the decision that could diminish or even terminate the sovereignty of the Slovak Republic. Therefore, this decision must be imperatively 'consulted' with the ultimate source of all state power and legitimacy, that is, with the people in a referendum.

This provision was introduced in the original wording of the Constitution in $1992,{ }^{15}$ that is, before the termination of the Czech and Slovak Federation on 31 December 1992. It was a reflection of the situation, in which the possibility of splitting up the existing federation was being constitutionally expected. At that time the referendum represented the only acceptable legal avenue for how to consult an issue of such significance directly with the people. ${ }^{16}$ Despite the importance of the issue and the constitutional obligation to hold a referendum, the separation of the Federation at the end of 1992 did not trigger a

15 The Slovak Constitution was adopted on 1 September 1992 by the Slovak National Assembly. However, the Slovak Constitution only became fully operational on 1 January 1993 when the independent Slovak Republic was established.

16 Art. 1(2) Constitutional Statute no 327/1991 on referendum ('The proposal to withdraw the Czech Republic or the Slovak Republic from the Czech and Slovak Federal Republic can only be decided by referendum'). 
'mandatory' referendum. The decision to split up the former 'brother nations' remained purely political. ${ }^{17}$

Nowadays, the constitutional provision relating to the mandatory referendum has become relevant again, as legal scholars ${ }^{18}$ and even the SCC itself $f^{19}$ discuss it in connection to the constitutional limits of the ongoing EU integration. In the future in this process, the Slovak Republic could hypothetically lose certain fundamental qualities and powers that define its state sovereignty. That procedure could, thus, reach the threshold of Article 7(1) of the Constitution in regard to 'entering into a union with other states', which would then require to be consulted directly with the Slovak citizens in a mandatory referendum.

\subsection{Optional (Citizen-initiated or Institution-initiated) Referendum}

All other forms of referendums at the national level are optional, which means that they may be held if specified constitutional pre-conditions are met. The power to call a referendum is an exclusive competence of the President of the Slovak Republic (the President). ${ }^{20}$ The President may only execute this power if he or she is 'requested by a petition signed by at least 350,000 citizens, or on the basis of a resolution of the National Council of the Slovak Republic, within 30 days after receiving the petition, or the resolution of the National Council of the Slovak Republic' ${ }^{21}$ The presidential power to call a referendum is, therefore, conditioned upon the delivery of the petition of citizens (citizen-initiated referendum) or the resolution of the Slovak Parliament (institution-initiated referendum).

The National Council of the Slovak Republic (National Council or Parliament) decides about the initiation of a referendum by a simple majority of votes. Under Article 96(1) of the Constitution the motion to pass a resolution of the National Council on calling a referendum may be introduced by members of parliament or by the Government.

The popular initiative of 350,000 citizens is not conditioned upon a decision of any other state organ. The right to initiate a referendum cannot be invoked individually, only by a constitutionally specified number of citizens. Interestingly, there is no time limit for collecting signatures. On the other hand,

17 It took place on the basis of the Constitutional Statute no 542/1992 on the dissolution of the Czech and Slovak Federal Republic adopted by the Federal Assembly.

18 See: Daniel Krošlák et al., Ústavné právo (Wolters Kluwer, 2016) 134-139.

19 Decision II. ÚS 171/05.

20 If there is no President in office or the President cannot execute his or her powers within the meaning of the Constitution, the power to call a referendum is temporarily executed by the Government of the Slovak Republic (Art. 105 Constitution).

21 Art. 95(1) Constitution. 
the number of citizens required to initiate a referendum is tremendously high, since 350,000 signatures represent almost 8 per cent of all voters (approximately 4.45 million people). If the initiative fulfils all constitutional prerequisites, the President is constitutionally obliged to call a referendum. ${ }^{22}$

The subject of an optional referendum must avoid certain specific constitutional limitations (see section 3.2.). It is, however, not constrained to be either proactive or rejective. Therefore, the referendum can introduce new issues or it can be aimed specifically against certain legislative acts.

The results of a referendum can only be considered valid if the participation of citizens reaches the constitutionally stipulated threshold, which is at least one half of eligible voters (a turnout quorum) and if the majority of the participating citizens endorses the proposed question(s) (an approval quorum). Under Article 94 of the Constitution only citizens of the Slovak Republic have the right to participate in a referendum: 'Every citizen of the Slovak Republic who has the right to vote in elections of the National Council of the Slovak Republic is entitled to participate in the referendum.' Without achieving these formal procedural prerequisites, no referendum can be considered valid and thus produce legal effects.

\subsection{Citizens' Agenda Initiative}

The right to petition is recognized under Article 27 of the Constitution. It stipulates that 'everyone has the right, alone or with others, to address requests, proposals and complaints to the state and local authorities in matters of public or other common interest.'

The SCC declared that this right embodies one of the forms of direct democracy in Slovakia. It is part of the principle of the sovereignty of citizens, which empowers them to participate in the administration of public affairs. ${ }^{23}$ The purpose of this right is to allow citizens to express their opinion directly and in relation to the legislative activity of the National Council. If the petition is signed by at least 100,000 citizens, it must be discussed in the National Council. ${ }^{24}$ The Parliament, however, is not obliged to legislate upon this citizens' proposal. ${ }^{25}$ Therefore, the right to petition does not limit the legislative power of the National Council. ${ }^{26}$ The only constitutional limitation of this right

\section{Art. 95(1) Constitution. \\ Decision PL. ÚS 42/95.}

24 Art. 133 (3) Rules of Procedure of the National Council of the Slovak Republic. Accessible (in Slovak language) here https://www.nrsr.sk/web/Static/sk-SK/NRSR/ Doc/zd_rokovaci-poriadok-20190821.pdf, accessed 10 June 2020.

25 Decisions III. ÚS 266/08, I. ÚS 38/94.

26 Decision IV. ÚS 409/2010. 
is that the petition cannot be aimed at restricting the fundamental rights and freedoms. ${ }^{27}$

\section{LEGAL LIMITS}

\subsection{Substantive Limits}

The Constitution prescribes one positive and three negative pre-conditions for the subject of a national optional referendum.

The positive pre-condition for questions posed in a referendum is formulated in Article 93(2) of the Constitution: 'A referendum can be used to decide also on other important issues of public interest.' What exactly could be understood as 'other important issues of public interest' was explained by the SCC in PL. ÚS 24/2014. It stated that:

the term 'public interest' is an uncertain legal expression ... However, without the necessity for a more or less precise definition of this concept, the Constitutional Court emphasizes that ... the requirement that a referendum can be organized on the basis of a petition supported by at least 350,000 citizens must be taken into account. The prerequisite of 350,000 or even more citizens asking for a referendum in a particular issue is a strong indication that this (question) is being transformed into an important issue of public interest.

In other words, the SCC requires the support of 350,000 citizens for an issue to satisfy the definition of an 'important issue of public interest' under Article 93(2) of the Constitution. That kind of support potentially elevates any issue into the scope of an optional national referendum.

In another important judgment, concerning the feasibility of revising the Constitution via the questions posed in the referendum, the SCC declared that the constitutional provisions did not contain any restrictions that would limit a constitutional revision initiated by a referendum. ${ }^{28}$

The negative substantive limits of the referendum are prescribed in Article 93(3) and in Article 99(2) of the Constitution. Even though these issues may be 'important issues of public interest', that is, be within the scope of Article 93(2) of the Constitution, they are temporarily or permanently excluded from the purview of an optional referendum.

Temporarily excluded from the scope of the optional referendum are those issues that were the subject of a referendum in the recent past. Article 99(2) of the Constitution stipulates that a referendum on the same subject matter

27 Art. 27(2) Constitution.

28 Decision II. 31/97. 
may be repeated only after three years from the day it was held. The provision prevents the same issue from being repeatedly put on the ballot, which could diminish the relevance of results achieved in a referendum.

Issues that are permanently excluded from the scope of the optional referendum are, according to Article 93(3) of the Constitution, 'the fundamental rights and freedoms, taxes, levies, and the state budget'. While shielding questions that deal with taxes, levies and the state budget from being consulted in referendums has been quite uncontroversial and understandable in regard to the preservation of a stable and predictable state income, the matter of 'fundamental rights and freedoms' caused certain interpretative complications. The constitutional protection of fundamental rights and freedoms is based on their individual character. The main purpose of excluding fundamental rights from direct democracy is to protect individuals against a majoritarian interference. Therefore, it should not be feasible to discuss their (non)existence in a referendum. Otherwise, the entire concept of individual protection could be undermined by a majoritarian decision. Ultimately, putting human rights to the vote in a referendum could lead to a legal repudiation of their existence.

The issue gained attention in 2014, when the President articulated doubts that the scope of proposed questions for the upcoming same-sex marriage referendum may be interfering with the constitutional limitation on 'fundamental rights and freedoms'. His doubts revolved around the question whether the fundamental rights and freedoms were completely banned from any consideration in a referendum. Therefore, the President filed the case with the SCC, asking whether the subjects of the referendum were in compliance with the Constitution.

In the PL. ÚS 24/2014 decision the SCC reviewed the constitutionality of the four proposed questions:29 (1) 'Do you agree that no cohabitation of persons other than a union between one man and one woman could be named marriage?' (2) 'Do you agree that neither same-sex couples nor groups shall be allowed to adopt children and subsequently raise them?' (3) 'Do you agree that no other cohabitation of persons than marriage should be granted special protection, rights and duties which are only granted to marriage and married couples by standards as of 1 March 2014 (especially acknowledgement or registration as a life partnership at a public authority, possibility to adopt a child by the second husband/wife of a parent)?' (4) 'Do you agree that schools should not require participation of children in classes dedicated to sexual

29 For more details on this case see Daniel Krošlák, 'The Referendum on the So-Called Traditional Family in the Slovak Republic' (2015) Central and Eastern European Legal Studies 149-167; Lucia Berdisová, 'K ne/súladu referenda o ochrane rodiny s Ústavou Slovenskej republiky’ (2014) Justičná revue 1246-1255. 
behaviour or euthanasia if their parents or the children themselves do not agree with the content of the lessons?'

In regard to the constitutional limitation on referendum questions dealing with fundamental rights and freedoms, the SCC held that it:

tends to understand Art. 93(3) of the Constitution as a ban to referendums on issues that could undermine the concept of fundamental rights and freedoms by lowering their standards resulting from international law, as well as from the national legal system to an extent that would threaten the rule of law principle. However, it is not possible to reject every question that concerns as little as possible the content of one of the fundamental rights and freedoms. Otherwise, this understanding would indeed deny the meaning and purpose of the referendum.

This statement was supplemented by a formulation that fundamental rights and freedoms were allowed to be expanded by a question posed in a referendum, but their understanding should never be restricted. The SCC also added that '[it] must always ensure that a possible extension of the standard of a particular fundamental right or freedom does not lead in parallel to a restriction of another fundamental right or freedom.' This assertion is again quite unclear and raises several other problems of interpretation. The most complicated issue is to ascertain how to raise 'the standard' of one fundamental right, while at the same time not influencing or diminishing the standard of another fundamental right - especially since so many fundamental rights are conflicting in their nature.

In reaching this conclusion, the SCC reviewed the Slovak legislation, as well as the ECtHR's case law in connection to the legal status of same-sex marriages and adoption. The SCC stated that the first and the second questions did not interfere with then-legislative status quo, already banning the marriages between the persons of same sex, as well as prohibiting the adoptions of children by unmarried couples. Therefore, these two questions were held constitutional.

The formulation of the third question was cumbersome, but it was generally understood that it implicitly dealt with the legal status of unmarried same-sex couples. The SCC, however, stated that the phrase 'no other cohabitation of persons' represents a broad range of relationships and it could not be suggested that it categorizes persons on the basis of their sexual orientation. The SCC declared that the case at hand only distinguished marriage and all 'other cohabitation of persons', which includes relations of both same-sex and opposite-sex couples. The formulation of the question clearly omitted the fact that the Slovak law already recognized several categories of cohabitation. The initiators of the referendum tried to constitutionally entrench an exclusive legal status of marriage against all other forms of cohabitation. That would, according to the SCC, result in lowering the standards of the fundamental right 
of protection against unauthorized interference with the family life. Therefore, the SCC declared this question unconstitutional.

The fourth question was found constitutionally irrelevant, as it was not imperative. Even if approved, it would require further statutory implementation, which would offer various possibilities for the legislator. Therefore, the question was not held unconstitutional.

The issue of fundamental rights has not been further elaborated or addressed in another SCC decision, thus many questions still remain unresolved.

\subsection{Formal Limits}

There are no requirements of unity of substance, unity of form, or unity of hierarchical level concerning the questions posed in a referendum recognized either by the Constitution or by the SCC case law.

However, the SCC held impermissible a question in the form of a specifically worded draft of a legislative enactment. ${ }^{30}$ The SCC stipulated that in the Constitution the legislative power was fashioned in two ways. It belongs not only to the National Council but also directly to the Slovak citizens. ${ }^{31}$ The referendum, however, cannot serve as a complete substitution for the legislative power of the Parliament. In that regard, the past practice that involved an attachment of a specifically worded draft of a legislative enactment, in order to limit involvement of the Parliament, if the referendum was successful, was declared unconstitutional. ${ }^{32}$ In other words, a successful referendum cannot generate a bill that the Parliament then has to promulgate without any deliberation or possibility to modify it. That practice would completely side-step the legislative power of the Parliament. Under Article 72 of the Constitution, the National Council is the only constitution-making and legislative body in the Slovak Republic and, therefore, the only channel through which the Slovak legal order can be modified. Thus, a successful referendum can only serve as a constitutional trigger that activates the power of the National Council to legislate. Implementation of the result of the referendum must remain within the discretion of Parliament. In other words, the SCC has banned specifically worded proposals from being subject to a referendum. Therefore, only questions of principle are generally permissible in referendums. This constitutional ban, however, places the enormously important power of implementation back in the hands of parliamentarians.

30 Decision PL. ÚS 31/97.

31 Decision II. ÚS 31/97.

32 Decision II. ÚS 31/97. 


\subsection{Core Constitutional Values as the Subjects of Referendums}

The referendum has reached an almost mythical pre-eminence in the Slovak constitutional discourse. The high turnout requirement ${ }^{33}$ has elevated the referendum in Slovakia to the heights of the ultimate will of the people, which is capable of any change within the constitutional realm. The reflection of this extraordinary character of a valid referendum has been formulated in a recent landmark decision of the $\mathrm{SCC},{ }^{34}$ in which the existence of an implicit (unamendable) material core of the Constitution has been announced. ${ }^{35}$ The decision formulated several constitutional principles as foundational: that the Slovak Republic is a democratic state based on the rule of law and the separation of powers forms the implicit core of the Constitution. These foundational principles can never be undone by any legislative power of the Parliament. The SCC, however, articulated one single exception through which an alteration of the material constitutional core would still be possible. It outlined that a modification would be possible 'by the decision of the original constitution-making body (the people) in the referendum' ${ }^{36}$ The SCC, thus, declared that the results of a referendum may not be subject to further constitutional limits. Even the material constitutional core is not immune against a change or complete annihilation by the results of a valid referendum. Thereby, the results of a referendum have been essentially equalled to the mythical 'pouvoir constituant'. This SCC declaration was an embodiment of a prevailing doctrinal position on the potential power of referendum in Slovakia. Thus, it is now almost unthinkable to fashion any additional substantive constitutional constraints on the results of a referendum. Similarly, any subsequent constitutional challenge of a valid referendum has been considered absurd. The only practical check against this 'nuclear' power of the referendum in Slovakia has been the elevated turnout quorum that historically prevented referendums from being successful. This threshold itself has produced a continual avalanche of public condemnation. ${ }^{37}$ Even though this criticism may seem appropriate, any modification of the

33 Slovakia's high constitutional turnout requirement for a valid referendum is not unique in the Central European region, see Anneli Albi, EU Enlargement and the Constitutions of Central and Eastern Europe (Cambridge University Press, 2005) 140.

34 Decision PL. ÚS 21/2014 [177].

35 For more details about this case see Simon Drugda, 'Slovak Constitutional Court Strikes Down a Constitutional Amendment - But the Amendment Remains Valid' (Blog of the International Journal of Constitutional Law, 25 April 2019) http://www iconnectblog.com/2019/04/slovak-constitutional-court-strikes-down-a-constitutional -amendment-but-the-amendment-remains-valid, accessed 10 June 2020.

36 Decision PL. ÚS 21/2014 [177].

37 Marek Domin, 'A Part of the Constitution Is Unconstitutional, the Slovak Constitutional Court has Ruled' (Verfassungsblog, 8 February) https://verfassungsblog 
turnout quorum must be accompanied by a complete reconsideration of the potential 'pouvoir constituant' consequences of the referendum. Otherwise, the referendum could produce unimaginably damaging results that could either diminish or even destroy the nature of the Slovak Republic as a democratic state based on the rule of law and the separation of powers.

\section{INSTITUTIONAL AND PROCEDURAL FRAMEWORK FOR REVIEWING COMPLIANCE WITH THE LEGAL LIMITS}

Both avenues of an optional referendum (by a vote of the National Council and by a popular initiative) are fully autonomous. The President has an obligation to examine whether the popular or parliamentary initiative fulfils all constitutional prerequisites. If it meets the procedural and substantive constitutional limits outlined above, the President has a straightforward constitutional duty to call a referendum within a period of 30 days. If the President has doubts regarding the constitutional conformity of the proposed referendum, he or she may refuse to call it.

Additionally, if the President has specific reservations about the subject of a referendum, that is, about the substantive framing of the question(s), he or she may initiate an ex ante judicial review before the SCC. ${ }^{38}$ The SCC will then decide upon its constitutionality. Article 95(2) of the Constitution stipulates that 'the President may, before calling a referendum, file with the Constitutional Court a petition for a decision whether the subject of the referendum, which should be organized on the basis of a citizens' petition or a resolution of the National Council ... is in compliance with the Constitution or constitutional statutes.' It is not the President's constitutional duty to initiate this type of proceeding. Such initiation rests fully upon his or her consideration.

This type of judicial review is further regulated in Article 102-109 of Act no. 314/2018 on the Constitutional Court. In addition to the general requirements, the proposal must contain the subject(s) of the referendum; the legal basis for the referendum (mandatory or optional; citizen-initiated or institution-initiated); the reasons which lead the President to doubt the constitutional conformity of the subject of the referendum; and an indication of the constitutional provision(s) that is (are) according to the President incompatible with the subject of the referendum. ${ }^{39}$ The parties to the subsequent proceedings

.de/a-part-of-the-constitution-is-unconstitutional-the-slovak-constitutional-court-has -ruled/, DOI: https://doi.org/10.17176/20190211-212614-0, accessed 10 June 2020.

38 For further elaboration see Milan Lalík, Tomáš Lalík, Zákon o Ústavnom súde Slovenskej republiky, Komentár (Wolters Kluwer SR, 2019) 340-341.

39 Art. 103 Act no. 314/2018 on the Constitutional Court. 
before the SCC are the President and the National Council. If the referendum was initiated by a citizens' petition, the parties to the proceedings are the President and the petition's committee. ${ }^{40}$ Before deciding, the President of the Court requests the opinion of the National Council and, if a referendum is to be called on the basis of a citizens' petition, the opinion of the petition's committee. Other experts may also submit their opinions without request. The SCC, however, is not obliged to take them into account. ${ }^{41}$

Article $125 \mathrm{~b}(3)$ of the Constitution indicates a 60 -day period during which the SCC is obliged to decide on the issue. ${ }^{42}$ The SCC's constitutional review suspends the time limit for the President to call a referendum. If the SCC declares the subject of a proposed referendum unconstitutional, it cannot take place.

The operative part, the reasoning and the instruction on the legal effects of the ruling, together with the dissenting opinions, shall be published in the Collection of Laws. The SCC decides which part of the reasoning of the judgment shall be promulgated in the Collection of Laws. ${ }^{43}$

Ultimately, if a referendum is called, it shall be held within 90 days from the day it was called by the President according to Article 96(2) of the Constitution. A referendum may not take place within 90 days prior to elections to the National Council of the Slovak Republic. ${ }^{44}$ But a referendum may be held on the day of elections to the National Council. ${ }^{45}$

\section{LEGAL EFFECTS OF REFERENDUMS}

The legal impact of a valid referendum can be vaguely deduced from the constitutional text. Consequently, the legal ramifications of the relevant constitutional provisions have been highly disputed. Several uncertainties have been previously addressed in the SCC's case law, but many others still remain.

First, the most obvious impact of a valid referendum is its generally binding character. This consequence can be deduced from the wording of Article 93(2) of the Constitution, which specifies that 'a referendum can be used to decide ...' The formulation implies the decisive character of a successful referendum. Therefore, its results should enjoy conclusive, not only counselling, effect(s). In 2014 the SCC reconfirmed that the results of a referendum do have

Art. 104 Act no. 314/2018 on the Constitutional Court.

Art. 105 Act no. 314/2018 on the Constitutional Court.

Similarly, Art. 106 Act no. 314/2018 on the Constitutional Court.

Art. 108 Act no. 314/2018 on the Constitutional Court.

Art. 97(1) Constitution.

Art. 97(2) Constitution. 
legal consequences and thus a valid referendum cannot be regarded as a vote without any legal relevance. ${ }^{46}$

Based on Article 98(2) of the Constitution, if a referendum is successful, the National Council has a constitutional duty to promulgate the proposals adopted in the referendum in the same way as it promulgates statutes. The constitutional construction 'in the same way as it promulgates statutes' generated numerous academic debates. ${ }^{47}$ The literal interpretation of this provision could suggest that by the promulgation of the results of a successful referendum in the official gazette for the publication of legal norms, they become instantaneously legally binding and directly applicable in the Slovak legal order.

According to one group of Slovak jurists, however, the results of a referendum can never be directly applicable. ${ }^{48}$ The constitutional expression 'in the same way as it promulgates statutes' should not be understood in the sense that a valid referendum (and its results) becomes legally binding immediately after it was published in the official gazette. Under this consideration, it ought to be rejected that the results of a successful referendum would become legally binding in the same manner as 'ordinary' statutes adopted by the Parliament, that is, to be generally and directly binding.

Other Slovak academics have been pleading for the direct applicability of certain results of a successful referendum. The applicability is limited, however, to those results that are capable of being directly applicable. The directly applicable results would include mostly, but not exclusively, those that could directly determine (clearly and precisely) the duties and obligations of individuals or legal entities. These referendum results would then create a separate source of law that would be enforceable. Consequently, the questions posed in a referendum should be (intentionally) formulated in a directly applicable manner. If not, they say, these questions do not fulfil the basic substantive precondition of Article 93(2) of the Constitution ('other important issues of public interest'), and thus cannot be posed in a referendum. ${ }^{49}$

The debate was conceptualized by the SCC in 1997, when it declared that 'a successful referendum has a constitutional relevance in the sense that participating citizens are instructing the Parliament to act in accordance with the proposal adopted in the referendum', ${ }^{50}$

46 Decision PL. ÚS 24/2014.

47 Drgonec (n 7) 1264-1265; Tomáš Lalík, 'Tracing constitutional changes in Slovakia between 2008-2016' (2017) 58 Hungarian Journal of Legal Studies 2, 122-124; Marek Domin, 'Formálno-právna povaha výsledku referenda' (2010) 62 Justičná revue $11,1247-1255$.

48 For the discussion see Giba (n 3), 223-225.

49 Drgonec (n 8) 248-249.

50 Decision II. ÚS 31/97. 
The articulated constitutional obligation to legislate, however, produced another source of constitutional discrepancy, this time linked to the incoherency between the mentioned constitutional command to legislate instigated by a successful referendum and the representative mandate of the member of parliament, which assumes that each member of parliament should be free from any influence or coercion. Under Article 73(2) of the Constitution the members of parliament 'execute their mandate personally according to their conscience and conviction and are not bound by any orders'. The prevailing interpretation of this obvious contradiction among academics indicated that the constitutional duty to accept the results of a successful referendum should exceptionally bind the MPs despite the constitutional nature of their mandate. ${ }^{51}$ Under this view, the constitutional obligation of the MPs should follow the general will of the people expressed in a referendum.

In contrast, the SCC rejected the possibility that the citizens are capable of enforcing their will upon the parliamentarians in 2014. The SCC stipulated that 'It is constitutionally impossible to instruct the MPs how to vote on a proposal adopted in a referendum'. ${ }^{52}$ Consequently, there is no exception of the MPs' representative mandate and the citizens can only hold them accountable politically, that is, during the next parliamentary elections.

Therefore, the legal force of the results of a successful referendum should hinge upon the nature of the implementing act adopted by the National Council. There are, however, several specificities of this rationale that must be taken into consideration.

Article 99(1) of the Constitution stipulates that '( $t$ )he National Council of the Slovak Republic may amend or annul the result of a referendum by means of constitutional statute no sooner than three years after the result of the referendum came into effect.' This provision explicitly shields the results of a referendum against any legislative intervention within three years. After this period, the results based on a successful referendum are protected against any legislative amendment that does not have constitutional relevance. Only a constitutional statute, approved by a constitutionally required parliamentary super-majority, is capable of reversing the will of the people expressed in a successful referendum.

The limited untouchability of the results of a referendum is fragile and deserves further elaboration. This logic would constitutionally protect even ordinary statutes that implement the results of a successful referendum into the legal system. How would a constitutionally permissible method to change the

${ }^{51}$ Boris Balog, Lívia Trellová, 'Povinnost' parlamentu prijat' zákon?/!' (2012) Právny obzor, 33

52 Decision PL. ÚS 24/2014. 
sub-constitutional legislation by a constitutional statute look? What would that mean for the legal system? These are the constitutionally relevant queries that ought to be addressed by the SCC in the future.

\section{REFERENDUMS AT THE SUBNATIONAL LEVEL}

The constitutional foundations of the referendum at the subnational level (that is, the municipal referendum and the referendum in the self-government regional units) are stipulated in Article 67 of the Constitution. It specifies that the territorial self-administration is performed at meetings of municipality residents, by a municipal referendum, by a referendum in a self-government regional unit, by the municipality bodies or the bodies of self-government regional unit. The execution of the local referendum and the referendum on the territory of a superior territorial unit shall be specified by statute.

The implementing statutes are Act no. 369/1990 Coll. on a municipal establishment (referendum at the municipal level) and Act no. 302/2001 on the self-government regional units (referendum at the level of self-government regional units). In regard to these legal acts, the SCC declared that the statutory regulation of the referendum at the subnational level has been inconsistent and lacks proper implementation. ${ }^{53}$ Therefore, it can be stated that the issue of direct democracy at the subnational level did not gain the appropriate attention of the national legislator that should regulate the issue comprehensively.

The referendum at the subnational level is being utilized to ascertain popular support for issues of municipal significance or vital importance for the self-government regional unit. The obligatory municipal referendum is called by the municipal council in case of (a) a merger or a dissolution of municipalities; (b) a recall of the mayor; (c) a petition request of 30 per cent of municipal inhabitants; (d) a change of the name of the municipality; or (e) if it is statutorily required. ${ }^{54}$ The municipal council may also call an optional referendum on any other important issue of local governance..$^{55}$

The obligatory referendum in the self-government regional unit takes place in case of a recall of the chairman of the self-government regional unit. The optional referendum may be called by the council of the self-government regional unit on any other important issue concerning the exercise of self-governance. It can be initiated either by a resolution of the council or by a petition of at least 30 per cent of inhabitants of the self-governance unit. ${ }^{56}$

53 Decision PL. ÚS 4/2016.

54 Art. 11a(2) Act no. 369/1990 Coll. on a municipal establishment.

55 Art. 11a(4) Act no. 369/1990 Coll. on a municipal establishment.

56 Art. 15(1) Act no. 302/2001 on the self-government regional units. 
The results of all mentioned subnational referendums are considered valid, if the turnout quorum reaches at least one half of the population of the particular subnational unit and simultaneously if the majority of the participating inhabitants endorses the proposed question(s). ${ }^{57}$

Regrettably, the legal duty of the municipal and regional bodies to follow the results of a successfully conducted referendum at the subnational level has been highly disputed. ${ }^{58}$ The results of subnational referendums are not regulated constitutionally and mostly remain in full disposal of local representatives.

\section{CONCLUSION}

The referendum in the Slovak Republic has been considered a highly relevant tool of direct decision-making mostly by constitutional scholars and other academics. The promise to involve the public opinion into important decision-making at the subnational or even at the national level has not yet lived up to the original expectations of the public.

The Constitution provides a quite amenable and loosely fashioned framework that constructs several possibilities of how and when to conduct a referendum. The previous pages identified three main reasons that have enormously complicated the practical usage of the referendum.

First, the initiation requirement of a petition signed by 350,000 citizens. This extremely high threshold ( 8 per cent of all eligible citizens) has not allowed to bring many diverse topics to the public discourse.

The second impediment has been the extremely high turnout quorum (50 per cent of all voters). The referendum has been regularly used by politicians who had not been capable of passing their proposals through the legislative process in the Parliament. Therefore, their counterparts have been consistently discouraging their constituents from participation in referendums. The high turnout threshold has made it relatively easy for the political parties to effectively torpedo any referendum attempts. Only once, in case of the $2003 \mathrm{EU}$ referendum, did all major political parties join their forces and heavily encouraged citizens to participate. That was the only time in history when a referendum was successful..$^{59}$ The referendum has, therefore, never been a platform for a societal debate, but has mostly only been used as a tool of currently marginalized political representatives.

57 Art. 11a(8) Act no. 369/1990 Coll. on a municipal establishment; Art. 15(5) Act no. $302 / 2001$ on the self-government regional units.

58 Trellová (n 8) 141-46.

59 See further Albi (n 33) 138-62. 
Lastly, as formulated by the SCC case law, the legal effects of valid referendums rest primarily in the hands of politicians in the process of implementation of the results. This necessary reconfirmation of the results in Parliament did not help to persuade citizens of the viability of popular initiatives.

The combination of these factors in three different stages of the referendum process have contributed to the merely hypothetical importance of its constitutional existence. The ambiguities of the constitutional text could have been slowly diminished or even removed by the practical usage of the referendum. This clarification could have made the requirements of a successful referendum more transparent, predictable and its results more acceptable to the general public. This process, however, has not happened. Numerous interpretative possibilities that are mentioned in this chapter have only been hypothetically constructed. The reasons for that are quite simple. Only eight referendum events have been held in the history of the Slovak Republic. ${ }^{60}$ Moreover, only one of them - the referendum on the accession to the EU - was successful. This was undoubtedly caused by the rigid initiation process that has not created more interpretative opportunities for the SCC to clarify the discrepancies of the constitutional text. The constitutional jurists and commentators have produced various opinions that sketch different avenues of how to construe the relevant constitutional provisions. Unfortunately, without the authoritative decisions of those actors that are constitutionally involved in the process of referendum, the hypothetical solutions simply cannot provide the much-needed predictability and clarity of the legal framework. Slovakia, therefore, lacks not only historical experience, but also its own practice with this instrument of direct democracy.

In the light of the latest SCC landmark decision, ${ }^{61}$ the shortcomings of the referendum process may gain a new light. According to the SCC's reasoning in this decision, even the implicit material constitutional core could be transformed by the results of a referendum. Therefore, a potentially simple relaxation of the turnout quorum could enable a minority of citizens to annihilate the constitutional foundations of the republic. That would be unacceptable. Therefore, if any change of the referendum will be proposed in the future, it is imperative to rethink the entire mechanism, especially those constitutional provisions that deal with the legal effects of a referendum. Any 'cosmetic' modifications that would just enable a referendum to be more effective without reconsidering its further impacts could have tragic consequences.

60 The second (failed) referendum in 1997 was even prevented from happening as the government left the last question off the ballot paper. For a list of referendums, see the official webpage of the Statistical Office of the Slovak Republic (https://slovak .statistics.sk/) accessed 8 May 2020.

61 PL. ÚS 21/2014. 
The historical experience with referendums in Slovakia has been quite gloomy so far. This, however, should not predict the future. Possibilities still exist for the people as well as for their representatives to approach referendums differently, not as a polarizing tool, but as a vital device for a direct and deep societal discussion, in which collaboration rather than division will be promoted. Undoubtedly, that would require the involvement of public education and the support from national and local authorities as well as from civil society. These are, however, indispensable pre-conditions for a referendum to function properly, not only in the Slovak Republic but worldwide. 